\title{
Response of temporal variation of soil moisture to vegetation restoration in semi-arid Loess Plateau, China
}

\author{
Lei Yang ${ }^{a}$, Wei Wei ${ }^{a}$, Liding Chen ${ }^{\mathrm{a}, *}$, Wenlin Chen ${ }^{\mathrm{b}}$, Jinglan Wang ${ }^{\mathrm{c}}$ \\ a State Key Laboratory of Urban and Regional Ecology, Research Center for Eco-Environmental Sciences, Chinese Academy of Sciences, Beijing 100085, China \\ ${ }^{\mathrm{b}}$ Health Assessment and Environmental Safety, Syngenta, Greensboro, NC 27409, USA \\ c School of Life Sciences, Tsinghua University, Beijing 100084, China
}

\section{A R T I C L E I N F O}

\section{Article history:}

Received 9 May 2013

Received in revised form 5 December 2013

Accepted 7 December 2013

\section{Keywords:}

Soil moisture

Soil desiccation

Ecological restoration

Introduced vegetation

Temporal stability

\begin{abstract}
A B S T R A C T
Soil moisture is fundamental to ecosystem sustainability in semi-arid regions, and characterizing the response of temporal soil moisture variation to different vegetation types is important for assessing the sustainability of vegetation restoration. In this study, the soil moisture among eight typical types of vegetation is investigated and compared during three rainy seasons. The temporal variations of soil moisture in the near-surface (0-0.4 m), sub-surface (0.4-1.0 m), and deep layers $(1.0-2.0 \mathrm{~m})$ are explored to evaluate the ecohydrological effect of vegetation restoration in the semi-arid Loess Plateau of China. The results show that soil moisture content decreases drastically after vegetation restoration, with no significant difference in near-surface soil moisture among the vegetation types but significant differences in the sub-surface and deep soil layers. Introduced vegetation is the main factor affecting the soil moisture deficit below near-surface layers. Secondly, soil moisture is temporally stable in the sub-surface and deep layers, especially in introduced vegetation. This indicates that introduced vegetation consumes excessive amount of soil moisture and induces temporally stable soil desiccation. Soil desiccation with temporal stability cannot provide enough available soil moisture for plants and will inevitably threaten the sustainability of vegetation restoration and the associated ecosystem services. Lastly, high planting density is the main cause of severe soil moisture deficit on a long-term temporal scale. Our study results suggest that the current planting density of introduced vegetation is too high in specific cases and should be optimized with local soil moisture conditions in semi-arid regions.
\end{abstract}

(C) 2013 Elsevier B.V. All rights reserved.

\section{Introduction}

Water is fundamental to the biophysical processes that sustain ecosystem functions, particularly in arid and semi-arid regions where tight coupling exists between ecosystem productivity, surface energy balance, and water source availability (Wang et al., 2012a). Specifically, the moisture stored in different soil layers is recognized as an important driver of the productivity and sustainability of semi-arid terrestrial ecosystems (Legates et al., 2011; Porporato et al., 2002). Because vegetation strongly affects the water cycle, the interactions between vegetation and soil moisture are fundamental for ecological processes in semiarid regions. This issue is particularly crucial in ecohydrology, and has recently been investigated in many studies. For example, Hupet and Vanclooster (2002) found that vegetation plays an important role on the temporal dynamics of soil moisture through evapotranspiration based on intensive measurements. In addition, the results of Chen et al. (2007) showed that vegetation type have a significant influence on soil moisture dynamics. Vivoni et al. (2008) revealed that vegetation can mediate the soil moisture response to precipitation and change the

\footnotetext{
* Corresponding author. Tel.: +8610 62943840; fax: +861062849014.

E-mail address: liding@rcees.ac.cn (L. Chen).
}

spatial distribution of soil moisture, and Yang et al. (2012a) found that plant growth conditions can change the spatial pattern of shallow and deep soil moisture in semi-arid regions. Vegetation can significantly influence soil moisture and its spatiotemporal patterns.

Researchers have more recently focused on understanding the relationship between spatiotemporal variation of soil moisture and soil texture, soil organic matter, topographic factors, and other factors (Meerveld and McDonnell, 2006; Qiu et al., 2001; Western et al., 1999). Temporal variations of soil moisture are important, particularly in arid and semi-arid environments, and have been widely investigated in various ecosystems (Brocca et al., 2007; Grassini et al., 2010; Sala et al., 1992; Wendroth et al., 1999). Research shows that different plant species can lead to different rainfall-runoff responses, and thus lead to temporal variation in soil moisture (Aranda et al., 2012; Cubera and Moreno, 2007; Jost et al., 2012). Furthermore, the temporal pattern of soil moisture was found to vary at different soil depths (Mohanty et al., 1998). Similar studies have been conducted in the Loess Plateau of China. For instance, a decline of soil moisture in the 0-1 $\mathrm{m}$ layers was found during the process of ecological restoration, and the soil moisture replenishment by rainfall during the rainy season was not sufficient to recharge the soil moisture storage (Chen et al., 2010). 
In the Chinese Loess Plateau, the "Grain-for-Green Program" was implemented on a large scale by the central government in 1999, with the goal of controlling serious soil erosion (Chen et al., 2010). Afforestation and the introduction of new grasses and shrubs have been the main types of vegetation restoration in this region. Consequently, the newly introduced vegetation has become the dominant vegetation type (Liu et al., 2008). The newly introduced vegetation usually consumes more soil moisture than native plants and thus rapidly depletes local soil moisture resources (Cao et al., 2011; Yang et al., 2012b). The high soil moisture consumption has had negative impacts, decreasing ecosystem services (Chazdon, 2008; Liu et al., 2008; Wang et al., 2011). It is possible that the large-scale vegetation restoration project is limited by the availability of soil moisture resources (Cao et al., 2011; Chen et al., 2008). The groundwater in the Loess Plateau is too deep and thus unavailable for soil evaporation and/or plant transpiration (Mu et al., 2003). For this reason, the soil moisture stored in different depths is critical for plant growth and serves as a key water source for sustaining ecosystems in this region (Chen et al., 2008; Yang et al., 2012b). The temporal variations of soil moisture at different depths may have varying responses to vegetation and play different roles in sustaining vegetation growth.

The vegetation in semi-arid regions consumes soil moisture not only from the surface layers but also other layers, so understanding the vertical distribution of soil moisture and the dynamics of such moisture is important for sustaining human-introduced vegetation restoration projects. The temporal dynamics of soil moisture in different layers under the influence of vegetation restoration have received limited attention. Understanding the effect of different plant species on moisture dynamics at different soil depths has several important implications. It is important for selecting optimal species for vegetation restoration efforts as well as many other scientific field and operational applications, especially in semi-arid regions. Thus, the objectives of the present study are to: (1) elucidate the influence of vegetation restoration on soil moisture content, (2) analyze the temporal variation of soil moisture under different vegetation types, and (3) identify factors responsible for soil moisture temporal variation among different soil layers.

\section{Materials and methods}

\subsection{Study area}

Longtan watershed $\left(35^{\circ} 43^{\prime}-35^{\circ} 46^{\prime} \mathrm{N}, 104^{\circ} 27^{\prime}-104^{\circ} 31^{\prime} \mathrm{E}\right)$, which is located in the western Loess Plateau, covers an area of $16.1 \mathrm{~km}^{2}$. The altitude of the watershed ranges from $1840 \mathrm{~m}$ to $2260 \mathrm{~m}$, with a highly fragmented landscape. It belongs to a typical semi-arid loess hilly region, with mean annual temperature of approximately $6.8{ }^{\circ} \mathrm{C}$ and mean annual rainfall of $386 \mathrm{~mm}$. Most rainfall occurs in the form of thunderstorms during the summer months from July to September. The potential annual evaporation (pan evaporation) is about $1649 \mathrm{~mm}$. These annual averages were derived from data provided by a meteorological station that is located $0.6 \mathrm{~km}$ from the watershed and represent 45-year averages (1961-2006). The rainfall pattern had a uniform distribution in the watershed based on five spatially distributed autorecording rain gauges during the 2008-2012 periods. The soil types in the study area are mainly composed of loess soil with low fertility and are vulnerable to soil erosion. The basic properties of this soil are a loose structure, high silt content (ca. 81\%), soil moisture field capacity $(0.180-0.240 \mathrm{~g} / \mathrm{g})$, and low organic matter content (ca. 0.2-2.9\%). The wilting point in the study area is $0.054 \mathrm{~g} / \mathrm{g}$ (Chen et al., 2007). Soil thickness varies from 40 to $60 \mathrm{~m}$.

The predominant land use types are sparse native grassland, rain-fed farmland, introduced vegetation lands. The native vegetation in the study area is sparse native grass dominated by the following species: bunge needlegrass (Stipa bungeana Trin.), common leymus (Leymus secalinus (Georgi) Tzvel.), Altai heterpappus (Heteropappus altaicus (Willd.) Novopokr.), and others. The introduced vegetation types are alfalfa (Medicago sativa), korshinsk peashrub (Caranana korshinskii), Siberian apricot (Armeniaca sibirica (L.) Lam.), Chinese red pine (Pinus tabulaeformis Carr.), and other varieties. In this semi-arid area, water shortages threaten economic development, sustainable human livelihoods, and environmental quality.

\subsection{Observation and analysis}

\subsubsection{Experimental sites design}

Experimental sites were selected for three different land use groups: native natural grassland, farmland, and introduced vegetation land. For the introduced vegetation land, five typical vegetation types were selected: alfalfa (M. sativa), korshinsk peashrub (C. korshinskii), Chinese arborvitae (Platycladus orientalis), Chinese red pine (P. tabulaeformis), and Siberian apricot (A. sibirica).

2.2.1.1. Native grassland. Native grassland is the dominant indigenous species community in this area. The main species are native grasses and herbs that demand little water. According to interviews from local farmers and stakeholders, natural grasslands were kept from human disturbance for at least 50 years.

2.2.1.2. Farmland. There are two types of farmland: traditional and abandoned. Traditional farmland is continuously cropped (continuous farmland), such as with potatoes, which are typically planted in May and harvested manually at the end of September or beginning of October. After harvest, a fallow period is followed from October to April in the next year. The abandoned farmland has been fallowed since 2002, and has plant species of native grasses and herbs. The land can be converted back to cropping at any time if a farmer decides to do so.

2.2.1.3. Introduced vegetation land. The lands with introduced vegetation were converted from traditional farmland by planting the introduced plants on traditional farmland. These types of vegetation include grassland (alfalfa), shrubland (peashrub), and forestland (Chinese arborvitae, Chinese red pine and Siberian apricot). Alfalfa planting was started in 2003 after the initiation of the "Grain-for-Green Program". In rainfall-deficit years, alfalfa is cut only once because of its poor growth, but it is cut twice in rainfall-rich years. The korshinsk peashrubs were planted in 1984 with a planting density of $2.22 * 10^{5}$ plants $/ \mathrm{km}^{2}$. Chinese arborvitae, Chinese red pine and Siberian apricot were planted with a density of $1.90 * 10^{5}$ plants $/ \mathrm{km}^{2}$ in 1980,1972 , and 1960 , respectively.

In this study, eight hillslopes with different vegetation covers were selected to measure the soil moisture content. All slopes were selected based on the upslope contributing area and flow direction. The upslope contributing area and flow direction for each sampling location were calculated using ArcGIS ${ }^{\circledR} 9.3$ (ESRI Inc., USA) based on DEM (Digital Elevation Model) with a resolution of $10 \mathrm{~m}$. Each hillslope has the same vegetation cover from the top to the foot of the hillslope along flow direction. Experimental sites on each hillslope had similar slope gradients. Three experimental sites located on the upper, middle, and downhill positions were selected on each hillslope. The upper, middle, and downhill sampling sites were at least $100 \mathrm{~m}$ apart (Fig. 1).

The soil properties are generally homogeneous in the entire study area. The soil moisture profile in the farmland was used as the reference to represent the conditions before human-introduced vegetation restoration. The difference in soil moisture content between the farmland and introduced vegetation reflects the response of soil moisture to the vegetation change. Soil moisture content in native grassland was used as the reference representing no human impact in the study area. Similarly, the difference in soil moisture content between native grassland and introduced vegetation indicates the degree of the soil moisture deficit relative to the initial soil moisture status. 


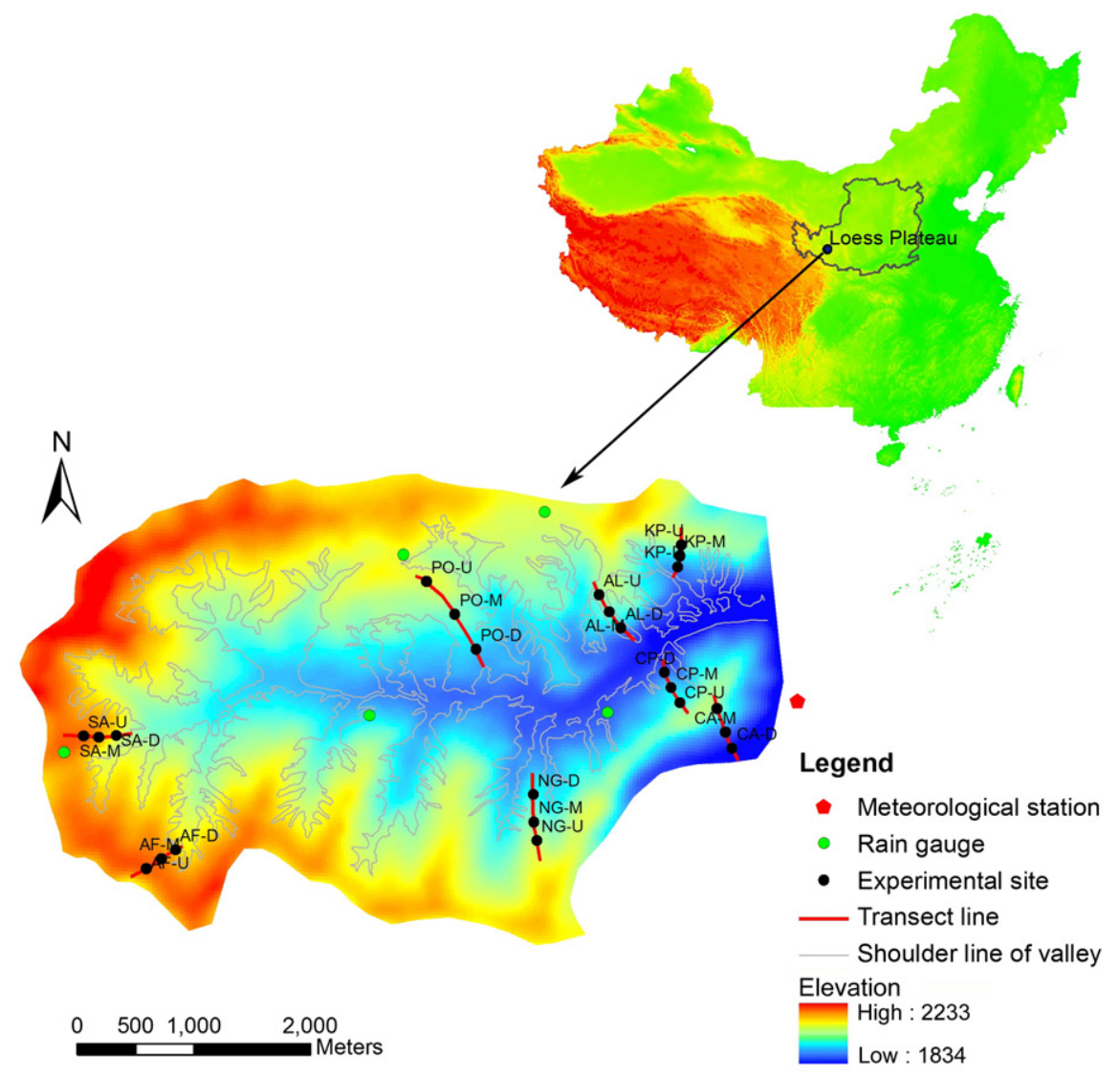

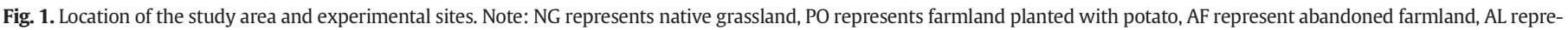
sents alfalfa, KP represents korshinsk peashrub, CP represents Chinese red pine, CA represents Chinese arborvitae and SA represents Siberian apricot.

\subsubsection{Data collection}

Biweekly soil moisture content measurements (at the beginning and middle of each month) were made in 20-cm increments to a depth of $2 \mathrm{~m}$ below the soil surface. In 2008, only the slope of the introduced vegetation land use was sampled between May and September. In 2009 and 2010, all land use types were sampled between April and October, which is the growing season in the area. At each experimental site (upper, middle, and downhill positions on the eight hillslopes), three sampling points were randomly chosen to take triplicate samples for obtaining the average soil moisture content at each soil depth.

Soil samples were taken using a drill and stored in sealed aluminum cases to prevent potential moisture loss before they were transported to the laboratory for measurement. All samples were measured for the soil moisture content (unit: $\mathrm{g} / \mathrm{g}$ ) using the gravimetric approach, which uses oven drying for $24 \mathrm{~h}$ at $105{ }^{\circ} \mathrm{C}$.

At each experimental site, undisturbed soil cores were collected for measuring soil bulk density in the top soil layer $(0-40 \mathrm{~cm})$. Soil bulk density and porosity were determined from the volume-mass relationship for each core sample. Soil samples at each experimental site were also collected to a depth of $1 \mathrm{~m}$ at $20-\mathrm{cm}$ intervals using a soil auger for the measurement of soil texture and organic matter content. Soil particle sizes were determined using the MasterSizer 2000 method. The proportion of the clay $(<0.002 \mathrm{~mm})$, silt $(0.002-0.02 \mathrm{~mm})$, and sand $(>0.02 \mathrm{~mm})$ contents were then calculated. Soil organic matter (SOM) was determined by dichromate oxidation method.

An investigation of vegetation was also conducted at every experimental site on each hillslope. At the introduced forest slopes, stand density (plants/ha), canopy density (percentage of area covered by tree canopy), tree height $(\mathrm{m})$, diameter at the tree height of $1.3 \mathrm{~m}$ above ground $(\mathrm{cm})$, and canopy width in a $10 \mathrm{~m} \times 10 \mathrm{~m}$ quadrat were recorded. At the introduced shrub slopes, plant height ( $\mathrm{m})$, canopy width in a $10 \mathrm{~m} \times 10 \mathrm{~m}$ quadrat and the canopy density of each quadrat were measured. Species composition, total herbaceous coverage, plant height, and biomass were measured in each herbaceous quadrat. General information about each experimental site is displayed in Table 1.

\subsection{Statistical methods}

The depth-averaged soil moisture content for each experimental site at each measurement time $\left(\theta_{i j}\right)$ was calculated by Eq. (1)

$\theta_{i j}=\frac{1}{i} \sum_{i=1}^{i} \theta_{i}$

where $i$ is the number of measurement layers at site $j$, and $\theta_{i}$ is the mean soil moisture content in layer $i$ calculated by three random sampling points. In the following section, the soil moisture content was calculated for the 0-0.4 m (near-surface layer), 0.4-1.0 m (sub-surface layer), and $1.0-2.0 \mathrm{~m}$ (deep layer), respectively.

The depth-averaged soil moisture content $\left(\theta_{m}\right)$ for each vegetation type at each measurement time was calculated by Eq. (2)

$\theta_{m}=\frac{1}{k} \sum_{k=1}^{k} \theta_{i j}$

where $k$ was the number of experimental sites for each vegetation type (Table 1 ). In this study, the $k=3$. 
Table 1

General information about experimental sites.

\begin{tabular}{|c|c|c|c|c|c|c|c|c|c|c|}
\hline \multirow[t]{2}{*}{ Land use } & \multirow[t]{2}{*}{ Sampling sites } & \multicolumn{3}{|c|}{ Topographical properties } & \multicolumn{6}{|c|}{ Soil properties } \\
\hline & & $\begin{array}{l}\text { Slope gradient } \\
\left({ }^{\circ}\right)\end{array}$ & $\begin{array}{l}\text { Slope aspect } \\
\left({ }^{\circ}\right)\end{array}$ & Slope position & $\begin{array}{l}\text { Bulk density } \\
\left(\mathrm{g} / \mathrm{cm}^{3}\right)\end{array}$ & $\begin{array}{l}\text { Porosity } \\
(\%)\end{array}$ & $\begin{array}{l}\text { Clay } \\
(\%)\end{array}$ & $\begin{array}{l}\text { Silt } \\
(\%)\end{array}$ & $\begin{array}{l}\text { Sand } \\
(\%)\end{array}$ & $\begin{array}{l}\text { SOM } \\
(\mathrm{g} / \mathrm{kg})\end{array}$ \\
\hline \multirow[t]{3}{*}{ Native grassland } & NG-U & 9 & 1 & Upper & 1.05 & 55.83 & 7.94 & 80.43 & 11.63 & 16.32 \\
\hline & NG-M & 30 & 358 & Middle & 1.05 & 54.82 & 6.63 & 84.07 & 11.63 & 15.18 \\
\hline & $\mathrm{NG}-\mathrm{F}$ & 31 & 358 & Foot & 1.07 & 52.73 & 6.56 & 84.41 & 9.03 & 17.16 \\
\hline \multirow[t]{6}{*}{ Farmland } & PO-U & 12 & 180 & Upper & 1.12 & 49.01 & 5.53 & 83.71 & 10.77 & 11.92 \\
\hline & PO-M & 12 & 180 & Middle & 1.11 & 48.03 & 6.39 & 84.06 & 9.55 & 11.57 \\
\hline & PO-F & 13 & 180 & Foot & 1.12 & 49.83 & 6.61 & 84.00 & 9.40 & 12.28 \\
\hline & AF-U & 14 & 65 & Upper & 1.00 & 56.26 & 6.32 & 82.27 & 11.40 & 13.09 \\
\hline & AF-M & 15 & 65 & Middle & 1.06 & 50.79 & 5.38 & 88.47 & 6.15 & 15.53 \\
\hline & AF-F & 15 & 65 & Foot & 1.04 & 55.07 & 7.35 & 85.87 & 6.78 & 16.35 \\
\hline \multirow[t]{15}{*}{ Introduced vegetation } & AL-U & 13 & 180 & Upper & 1.10 & 53.06 & 6.66 & 74.73 & 18.61 & 9.98 \\
\hline & AL-M & 14 & 181 & Middle & 1.09 & 54.52 & 7.16 & 80.80 & 12.04 & 10.94 \\
\hline & AL-F & 14 & 183 & Foot & 1.08 & 55.36 & 7.82 & 78.08 & 14.10 & 11.82 \\
\hline & KP-U & 32 & 180 & Upper & 1.10 & 50.56 & 5.47 & 79.46 & 15.07 & 9.71 \\
\hline & KP-M & 32 & 180 & Middle & 1.14 & 48.99 & 5.40 & 78.41 & 16.19 & 9.76 \\
\hline & KP-F & 30 & 180 & Foot & 1.14 & 49.01 & 4.95 & 82.78 & 12.27 & 8.19 \\
\hline & $\mathrm{CP}-\mathrm{U}$ & 7 & 345 & Upper & 1.01 & 52.08 & 5.48 & 81.69 & 12.83 & 9.68 \\
\hline & CP-M & 22 & 340 & Middle & 1.05 & 54.76 & 5.95 & 77.92 & 16.13 & 7.45 \\
\hline & $\mathrm{CP}-\mathrm{F}$ & 23 & 359 & Foot & 0.88 & 51.91 & 4.94 & 82.10 & 12.96 & 11.04 \\
\hline & CA-U & 23 & 174 & Upper & 1.08 & 52.07 & 5.57 & 78.49 & 15.94 & 10.72 \\
\hline & CA-M & 25 & 149 & Middle & 1.13 & 51.81 & 5.03 & 82.32 & 12.65 & 10.69 \\
\hline & CA-F & 24 & 150 & Foot & 1.16 & 51.02 & 5.43 & 80.51 & 14.05 & 5.81 \\
\hline & SA-U & 26 & 165 & Upper & 1.19 & 48.91 & 5.14 & 82.66 & 12.20 & 9.37 \\
\hline & SA-M & 24 & 126 & Middle & 1.06 & 50.31 & 5.81 & 77.51 & 16.68 & 7.95 \\
\hline & SA-F & 22 & 135 & Foot & 1.23 & 47.59 & 4.88 & 84.88 & 10.24 & 13.89 \\
\hline
\end{tabular}

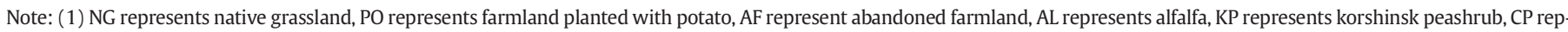

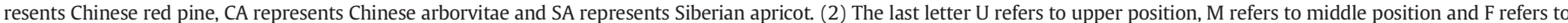

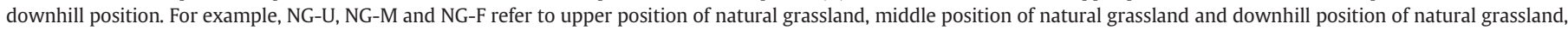
respectively.

The temporal- and depth-averaged soil moisture content of each vegetation type was calculated by Eq. (3)

$\bar{\theta}_{m}=\frac{1}{n} \sum_{n=1}^{n} \theta_{m}$

where $n$ is the number of measurement times during growing seasons.

The temporal standard deviation (SD) and coefficient of variation (CV) of the average soil moisture content for each soil layer were calculated over all measurement times. The calculated SD and CV were used as estimators of the temporal stability of the soil moisture content in each soil layer. Smaller values of SD and CV indicate a tendency of being more temporally stable.

Basic population statistics, including mean values (Mean), standard deviations (SD), and the coefficient of variation (CV), were reported for each soil layer over the study period (2008-2010). One-way ANOVA was used to assess the contribution of different vegetation cover types to the overall variation in the soil moisture variables. Multiple comparisons were made using the least significant difference (LSD) method. In addition, the relationships between soil moisture content and environmental factors (such as soil properties and topographical parameters) were identified through bivariate correlation analysis. SPSS ${ }^{\circledR}$ (Version 18.0) was used for all statistical analyses in the present study.

\section{Results}

\subsection{Variations in soil moisture among different vegetation types}

Soil moisture varied by both vegetation types and soil depth (Table 2). The temporal-averaged soil moisture in near-surface had a relatively higher value than that in sub-surface, and deep layer had the lowest soil moisture. Farmland had significantly higher soil moisture content in sub-surface and deep soil layers as compared with

Table 2

Temporal-averaged soil moisture content by vegetation.

\begin{tabular}{|c|c|c|c|c|c|c|c|c|}
\hline Land use & Land use sub-groups & Vegetation & $\begin{array}{l}\text { Near-surface } \\
0-0.4 \mathrm{~m} \\
(\mathrm{~g} / \mathrm{g})\end{array}$ & SD & $\begin{array}{l}\text { Sub-surface } \\
0.4-1.0 \mathrm{~m} \\
(\mathrm{~g} / \mathrm{g})\end{array}$ & SD & $\begin{array}{l}\text { Deep-layer } \\
1.0-2.0 \mathrm{~m} \\
(\mathrm{~g} / \mathrm{g})\end{array}$ & SD \\
\hline Native grassland & Native grassland & Native grasses and herbs & $0.078 \mathrm{bc}^{*}$ & 0.035 & $0.067 \mathrm{bg}$ & 0.006 & $0.065 b$ & 0.003 \\
\hline \multirow[t]{2}{*}{ Farmland } & Farmland & Potato & $0.100 \mathrm{a}$ & 0.030 & $0.112 \mathrm{a}$ & 0.007 & $0.108 \mathrm{a}$ & 0.009 \\
\hline & Abandoned farmland & $\begin{array}{l}\text { Abandoned farmland with } \\
\text { native grasses }\end{array}$ & $0.098 \mathrm{a}$ & 0.028 & $0.098 \mathrm{c}$ & 0.011 & $0.089 c$ & 0.005 \\
\hline \multirow[t]{5}{*}{ Introduced vegetation lands } & Grassland & Alfalfa & $0.105 a$ & 0.037 & $0.070 \mathrm{~b}$ & 0.010 & $0.062 \mathrm{~d}$ & 0.004 \\
\hline & Shrubland & Peashrub & $0.074 \mathrm{c}$ & 0.033 & $0.048 \mathrm{e}$ & 0.006 & $0.051 \mathrm{e}$ & 0.003 \\
\hline & Forestland & Siberian apricot & $0.080 \mathrm{c}$ & 0.031 & $0.056 f$ & 0.008 & $0.054 \mathrm{f}$ & 0.004 \\
\hline & & Chinese red pine & $0.101 a$ & 0.034 & $0.064 \mathrm{~g}$ & 0.005 & $0.058 \mathrm{~g}$ & 0.002 \\
\hline & & Chinese arborvitae & $0.069 \mathrm{~cd}$ & 0.027 & $0.052 \mathrm{~h}$ & 0.005 & $0.056 f$ & 0.005 \\
\hline
\end{tabular}

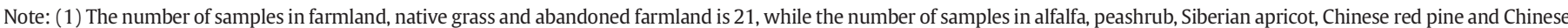
arborvitae is 29 .

* Means with the same letter in the same column are not significantly different at the 0.05 level (LSD test). 
other vegetation types. Compared with native grassland and farmland, soil moisture in introduced vegetation had significantly lower value in all soil layers. Lower soil moisture content indicates less available
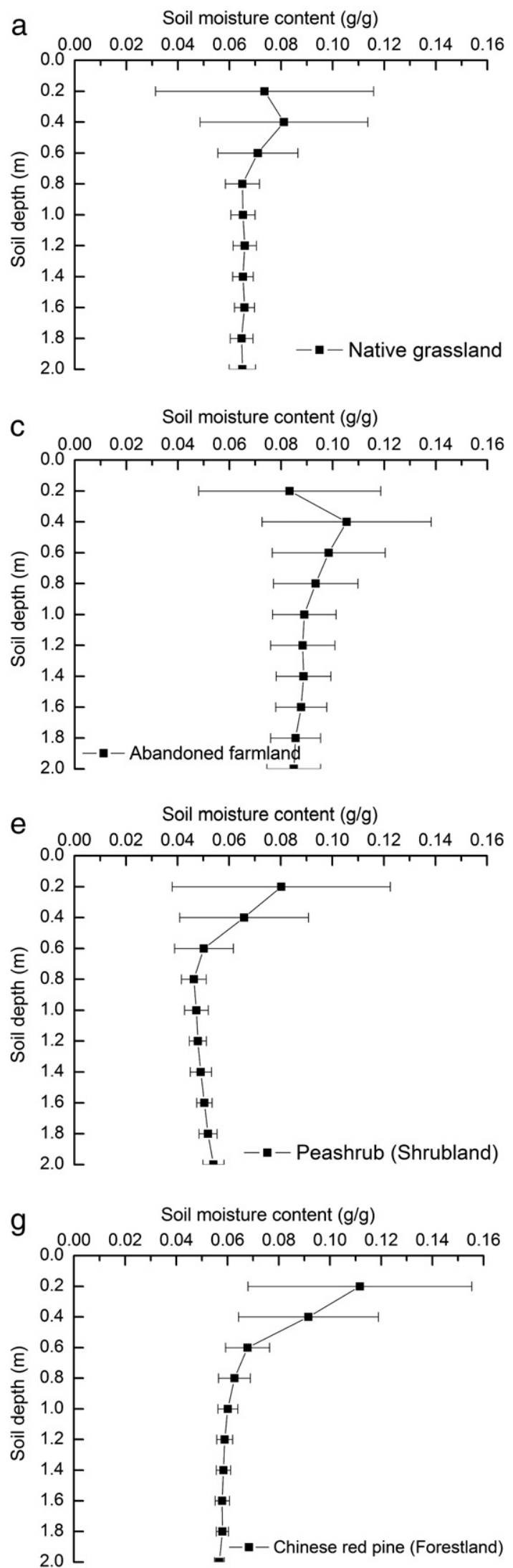

water resources for sustaining plant growth, especially for these high water consuming plants. A significant difference was found between different vegetation types in the LSD test, especially in the sub-surface
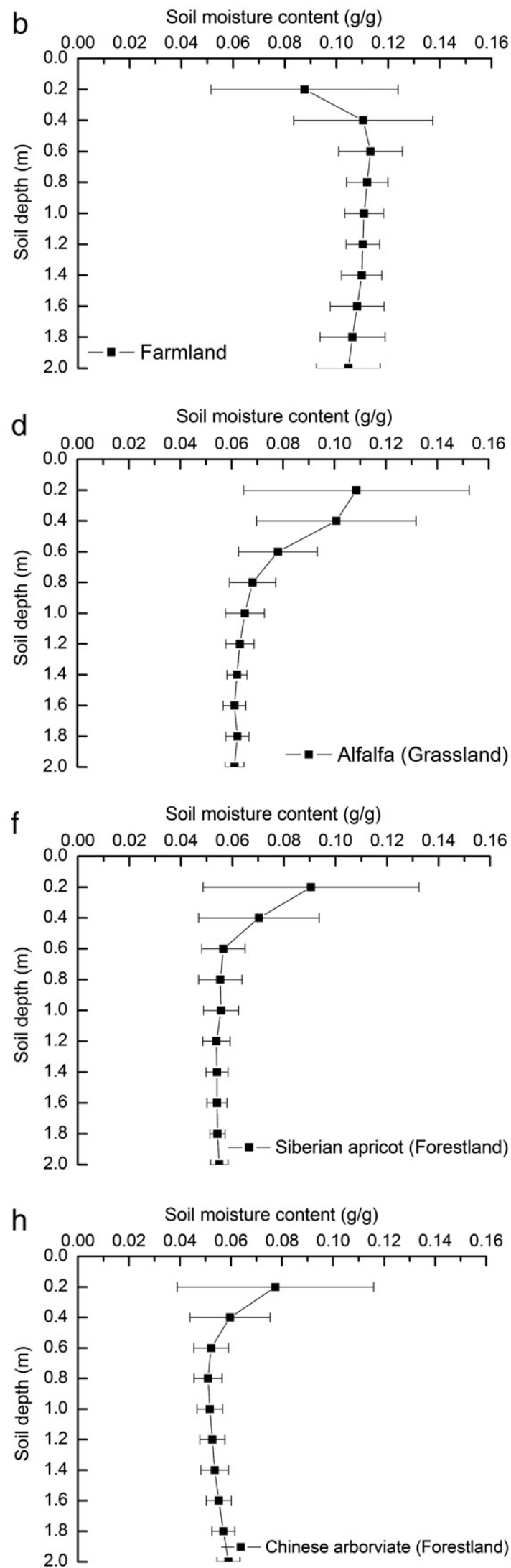

Fig. 2. Vertical distribution pattern of temporal-averaged soil moisture content by vegetation type. Note: The error bars indicate standard deviation (SD). 
and deep layers (Table 2). This result indicates that different plant species have a significant influence on soil moisture in both sub-surface and deep layers.

\subsection{Vertical soil moisture pattern by vegetation type}

The temporal patterns of soil moisture content in the soil profiles are displayed in Fig. 2. The temporal-averaged soil moisture content in near-surface layer was higher than that in deeper layers due to rainfall replenishment even though very low soil moisture content could occur between rainfall events. The SD value is relatively high in nearsurface layer, indicating high temporal variation. In contrast, temporal changes in soil moisture content appear to be smaller in sub-surface and deep soil layers, as reflected in the decreasing SD values with increasing soil depth for all vegetation types.

The vertical distribution pattern of soil moisture varied by vegetation type. For example, the SD values of soil moisture content for farmland and abandoned farmland were noticeably higher than that in other types of vegetation (Fig. 2a, c). The lower SD of soil moisture content in the introduced vegetation indicated less temporal changes and little moisture replenishment by rainfall. This is probably due to more plant interception and higher plant uptake by the introduced vegetation in the near-surface soil layer, thus reducing deep soil moisture recharge (Markewitz et al., 2010).

\subsection{Temporal changes of soil moisture by vegetation type}

Temporal patterns of soil moisture content in three different layers are shown in Fig. 3. The soil moisture content in near-surface layer changed seasonally corresponding to rainfall (Fig. 3a). Higher soil moisture content was associated with high precipitation among all vegetation types. During the growing season, high soil moisture content appeared from July to September and low values appeared from May to June.

Compared with near-surface layer, temporal changes of soil moisture content in sub-surface layer were relatively stable (Fig. 3b), and significant differences were found in the soil moisture content between different types of vegetation (Fig. 3b, Table 2). The soil moisture in subsurface layer was less affected by rainfall when compared with that in near-surface layers for all vegetation types, and higher soil moisture content appeared from August to September. The soil moisture levels in farmland, abandoned farmland, alfalfa grassland, and native grassland in the sub-surface layer were more prone to be affected by rainfall than other types of introduced vegetation. However, soil moisture in shrubland (peashrub) and forestland (Siberian apricot, Chinese red pine and Chinese arborvitae) showed relatively low temporal variation, indicating a more temporally stable soil moisture at this depth.

The lowest level of temporal variation in soil moisture appeared in deep-layer (Fig. 3c, Table 2). The CV values of soil moisture content in the deep-layer were all lower than 0.10 , as shown in Table 3 . Compared with farmland and abandoned farmland, the soil moisture in native grassland, shrubland and forestland was relatively unaffected by annual precipitation. On the other hand, the $\mathrm{CV}$ of depth-averaged soil moisture content varied by vegetation type. For example, the $\mathrm{CV}$ values of soil moisture content in farmland and alfalfa grassland were both 0.09 , but the value in Chinese red pine was only 0.04 . Interestingly, the soil moisture under alfalfa covers was relatively higher than that under other types of introduced vegetation, and was even higher than that in native grass cover (Fig. 3c).

\subsection{The correlation between soil moisture and soil/vegetation properties}

The correlations between depth-averaged soil moisture content and soil/vegetation properties are given in Fig. 4. In near-surface layer, the soil moisture content was more prone to affect by bulk density and canopy density. However, the soil moisture content in the sub-surface and deep layers showed a relatively weaker relationship with these two factors. The soil moisture content in sub-surface and deep layers was obviously influenced by clay content and soil organic matter than that in near-surface layers. These results are similar to the findings in previous studies (Jin et al., 2011; Van Pelt and Wierenga, 2001).

The correlations between the CV of depth-averaged soil moisture content and soil/vegetation properties are given in Fig. 5. The CV and bulk density show an obviously positive relationship in near-surface layers, with no significant relationship found in the sub-surface and deep layers. The CV and canopy density show a slightly negative correlation in the near-surface layer. However, no significant relationship was found between CV and SOM, clay content. This result indicated that the bulk density and canopy density may affect the temporal stability of soil moisture in near-surface layers.

\section{Discussion}

\subsection{The effect of vegetation restoration on vertical soil moisture distributions}

In semi-arid areas, the surface soil moisture is more prone to be affected by rainfall, vegetation transpiration, and soil evaporation (Seneviratne et al., 2010; Teuling and Troch, 2005). Relatively low soil moisture is expected due to high evapotranspiration in these regions. However, the relatively lower value of temporal-averaged soil moisture appeared at the depths below $0.4 \mathrm{~m}$ in this study. This was particularly true in areas with introduced vegetation (Table 2, Fig. 2). This is somewhat contradictory with the findings in previous studies (Fu et al., 2003, Mishra and Singh, 2010). Although having relatively higher soil moisture content in the near-surface layer due to rainfall replenishes, the SD and CV of soil moisture showed high temporal changes. This indicates that the soil moisture in these layers may not be a stable water source for plant growth, especially for introduced vegetation, which may change the ability of the soil to redistribute water vertically and horizontally (Wang et al., 2012a). In the current study, soil moisture content in introduced vegetation was low and little replenished by annual rainfall below $0.4 \mathrm{~m}$ based on the temporal variations presented Fig. $3 \mathrm{~b}$ and $\mathrm{c}$. This result indicates that soil desiccation changed little due to low infiltration for the introduced vegetation.

It should be noted that soil moisture below the surface layers was an important water source for introduced vegetation in initial years (Chen et al., 2008; Fu et al., 2012). In this study, the soil moisture in farmland served as the reference before human-introduced vegetation restoration. Compared with farmland, the soil moisture in introduced vegetation was low and less affected by annual precipitation below $0.4 \mathrm{~m}$ (Fig. 2). This may limit the water resources that are available for plant growth after years of growth, mainly because introduced plants consume excessively amounts of soil moisture stored in the sub-surface and deep layers. Soil moisture below the depth of $0.4 \mathrm{~m}$ could be affected by plant root systems (February and Higgins, 2010), resulting in the driest zone as compared with the upper layers. This may explain the relatively low soil moisture in the sub-surface and deep layers. Similar results were also reported by other researchers. For example, Weltzin and McPherson (1997) found that mature trees use water from deeper soil layers than grasses in savanna ecosystems.

Root water uptake is a main process determining soil moisture dynamics. The information on root distribution is very important for understanding hydrological processes in semi-arid ecosystems. Han et al. (2009) and Li et al. (2003) found that the root system of native grassland were mainly distributed in layers of $0-0.5 \mathrm{~m}$. Du et al. (2007) found the main root of abandoned farmland were mainly distributed in depth of 0-0.4 m. Different with native grassland and abandoned farmland, Wang et al. (2010) measured root indices (length density, root weight density, root surface area density, and root average diameter) and found that the roots of alfalfa and korshinsk peashrub can extend though the 0-3 $\mathrm{m}$ and 0-6 $\mathrm{m}$, respectively. Yang et al. (2012c) 
a Near-surface: 0-0.4 m

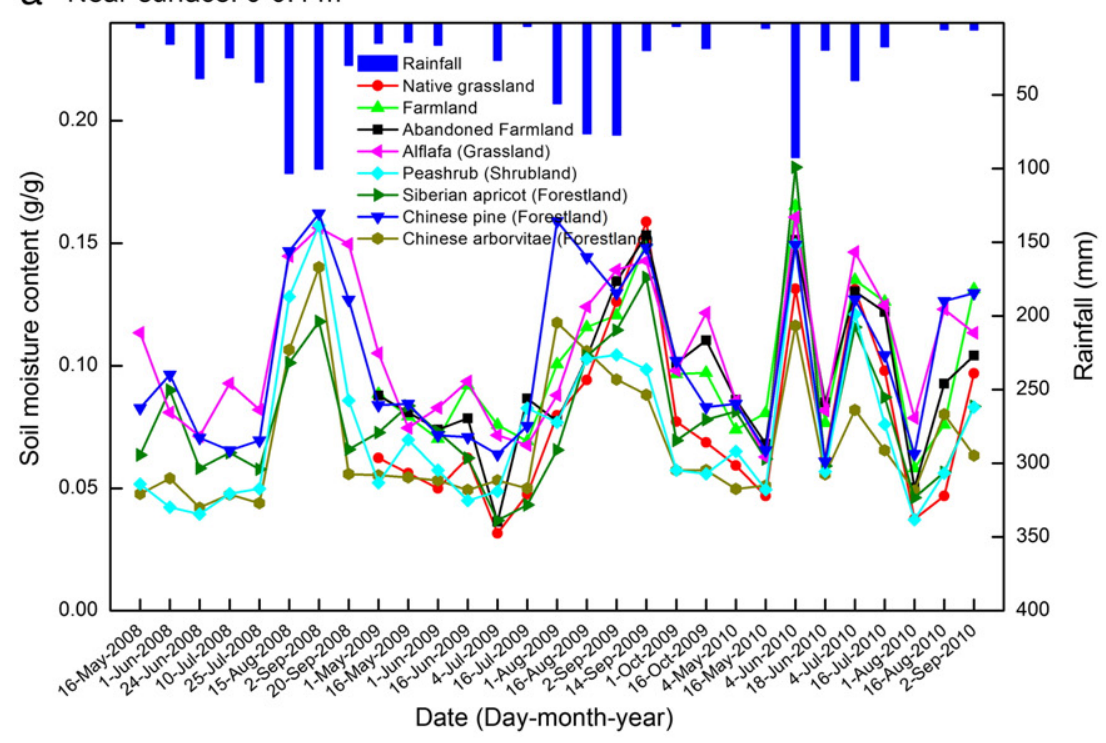

b Sub-surface: 0.4-1.0 m

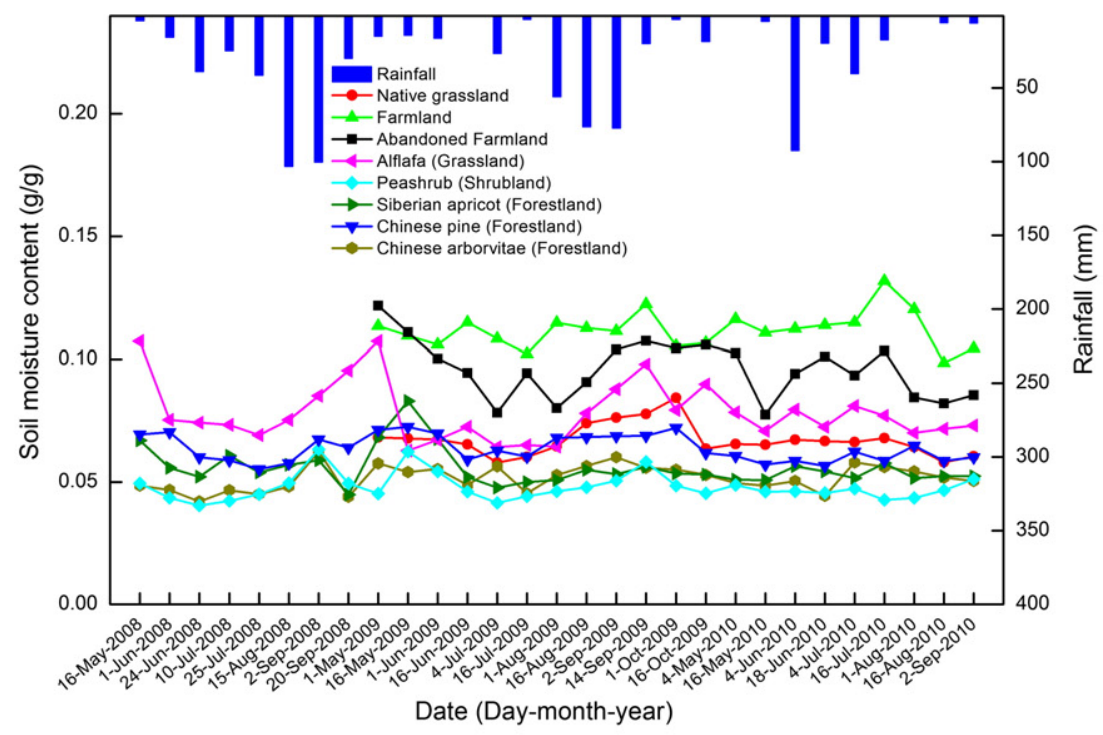

C Deep-layer: 1.0-2.0 m

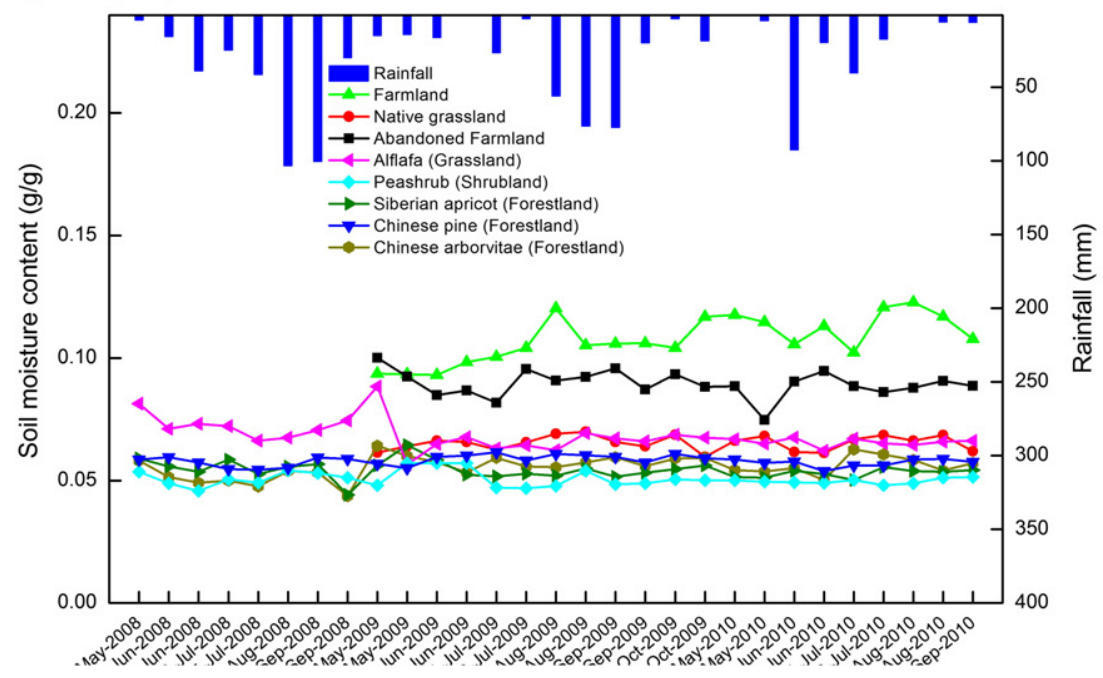

Fig. 3. Temporal pattern of depth-averaged soil moisture content by vegetation type. 
Table 3

Coefficient of variation for depth-averaged soil moisture content by vegetation type.

\begin{tabular}{|c|c|c|c|c|c|}
\hline Land use & Land use sub-groups & Vegetation & $\begin{array}{l}\text { Near-surface } \\
0-0.4 \mathrm{~m}\end{array}$ & $\begin{array}{l}\text { Sub-surface } \\
0.4-1.0 \mathrm{~m}\end{array}$ & $\begin{array}{l}\text { Deep-layer } \\
1.0-2.0 \mathrm{~m}\end{array}$ \\
\hline Native grassland & Native grassland & Native grasses and herbs & 0.45 & 0.10 & 0.05 \\
\hline \multirow[t]{2}{*}{ Farmland } & Farmland & Potato & 0.30 & 0.07 & 0.09 \\
\hline & Abandoned farmland & $\begin{array}{l}\text { Abandoned farmland with } \\
\text { native grasses }\end{array}$ & 0.28 & 0.11 & 0.06 \\
\hline \multirow[t]{5}{*}{ Introduced vegetation lands } & Grassland & Alfalfa & 0.28 & 0.15 & 0.09 \\
\hline & Shrubland & Peashrub & 0.44 & 0.12 & 0.06 \\
\hline & Forestland & Siberian apricot & 0.38 & 0.14 & 0.07 \\
\hline & & Chinese red pine & 0.33 & 0.08 & 0.04 \\
\hline & & Chinese arborvitae & 0.39 & 0.10 & 0.08 \\
\hline
\end{tabular}

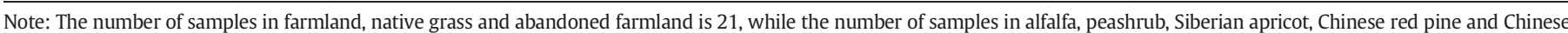
arborvitae is 29 .

found that $32 \%$ of root system of alfalfa were mainly distributed in depth of $0-0.4 \mathrm{~m}$ and other root system were uniformly distributed in depth of $0.8-3.0 \mathrm{~m}$. Cheng et al. (2009) found that most of fine root of korshinsk peashrub (70.7\%) were presented in the upper $1.0 \mathrm{~m}$. However, they also found that soil layer of 1.0-2.0 m depth also played an important role in providing water for peashrub plants and the plants tend to extend deeper roots in loess soils. Han et al. (2007) measured the root systems of Chinese arborvitae and Chinese red pine and found the fine root systems in Loess Plateau were mainly distributed in depth of $0.4-0.8 \mathrm{~m}$, but developed to more deep layers. Zhao and $\mathrm{Li}$ (2002) found that the root system of Siberian apricot distributed deeper than $1.0 \mathrm{~m}$ and concentrated in depth of 0.1-0.7 m. Based on the above discussion, the introduced vegetation usually have deeper root systems below the near-surface layers and consume more soil moisture than farmland and native grassland.
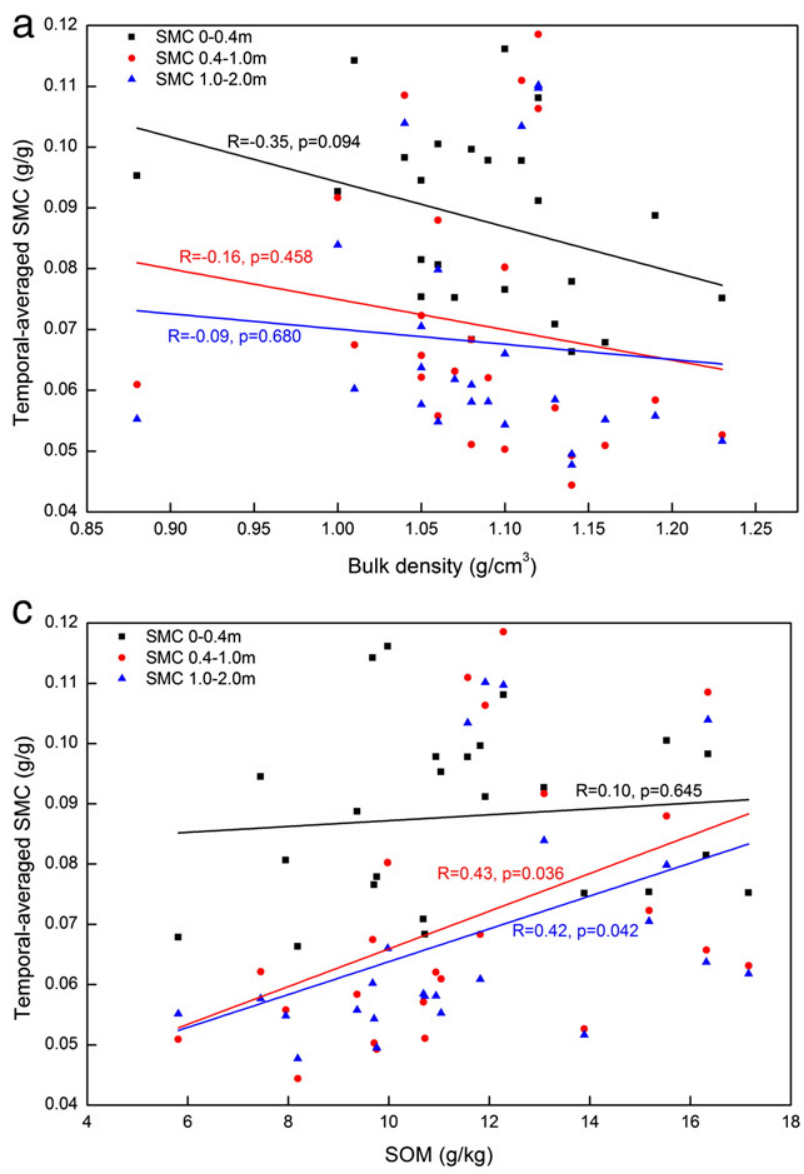

The response of soil moisture to rainfall in semi-arid areas varied by soil depth. Takagi and Lin (2012) found clear seasonal changes in soil moisture in near-surface layers during rainy seasons. However, de Souza et al. (2011) found an increase in the temporal stability of soil moisture in deeper soil layers as compared with upper layers. In the present study, the soil moisture in near-surface layers varied seasonally with annual precipitation among all vegetation types. More temporally stable soil moisture appeared under near-surface layers (Figs. 3b, 4c). The SD and CV values of soil moisture content decreased with increasing soil depth, especially in the cases of introduced vegetation (Fig. 2, Table 3). Furthermore, the significant difference in soil moisture between different types of introduced vegetation in the sub-surface and deep layers indicates that the vegetation type had significant influences on soil moisture content at these depths.
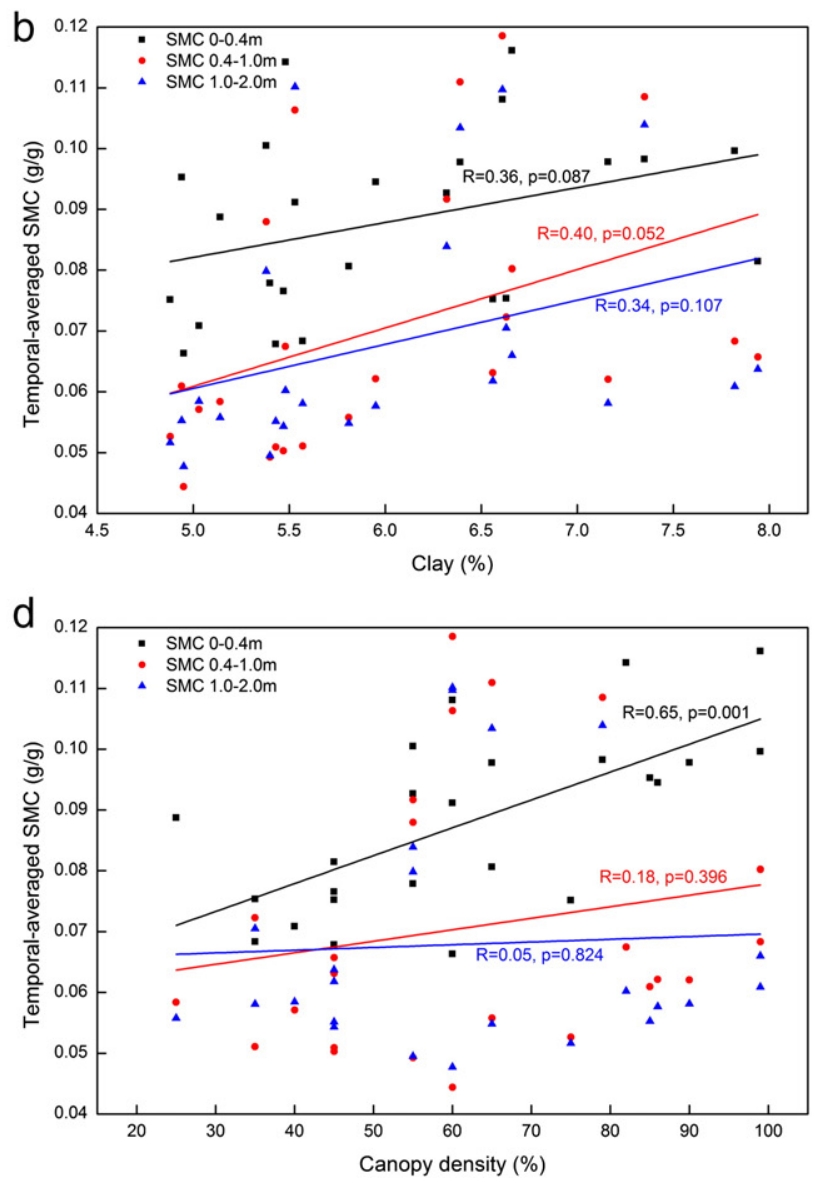

Fig. 4. Correlations between soil moisture content (SMC) and bulk density, clay content, SOM, and canopy density. 

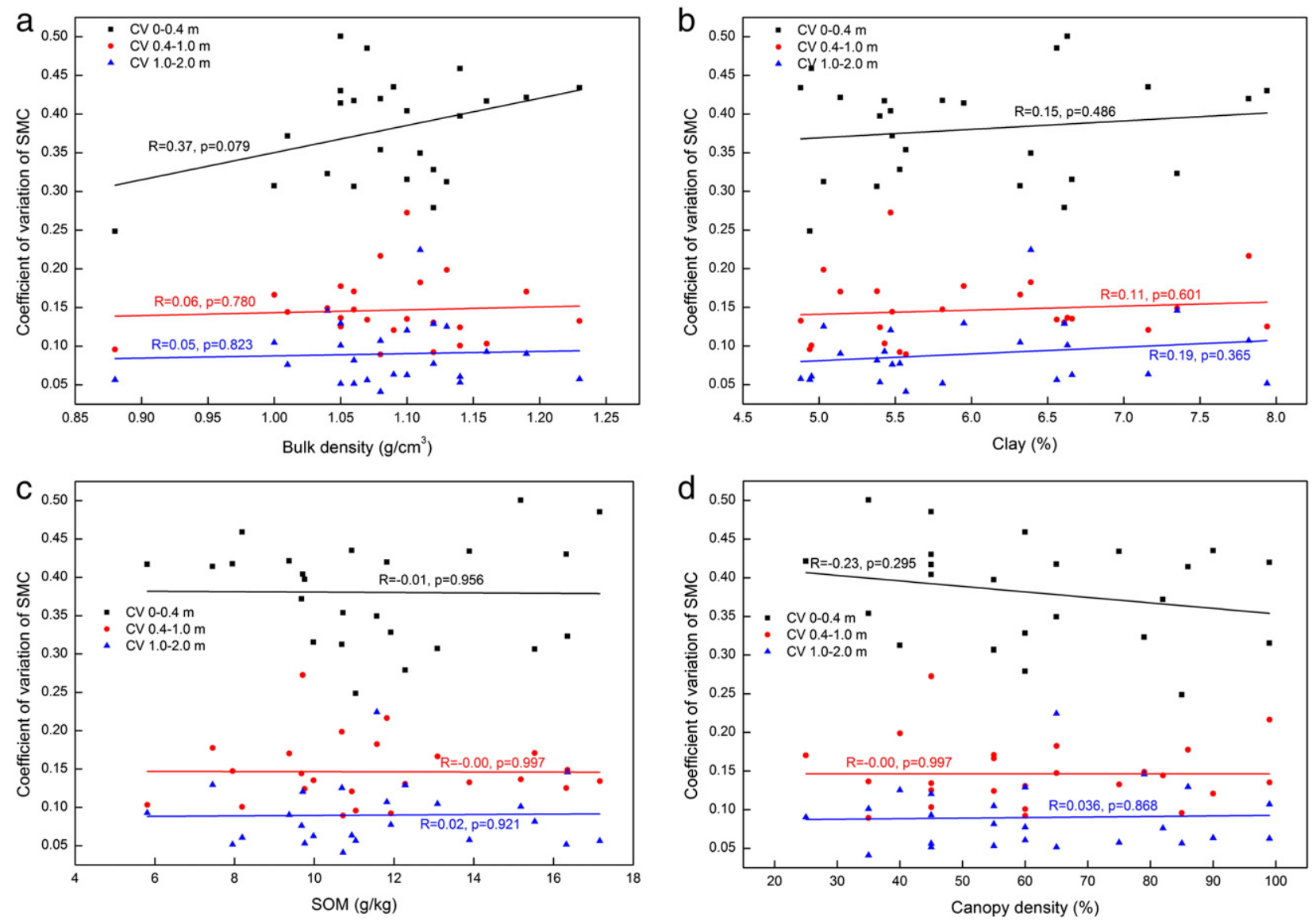

Fig. 5. Correlations between the coefficient of variation (CV) for soil moisture content (SMC) with bulk density, clay content, SOM and canopy density.

\subsection{The influence of vegetation restoration on temporal soil moisture} changes

Vegetation restoration affects water balance by increasing evapotranspiration and reducing runoff (Aranda et al., 2012, Sun et al., 2006, Wei et al., 2010). In fact, vegetation introduced a determining factor in soil moisture in semi-arid environment (Gómez-Plaza et al., 2000). Gao et al. (2011) found that locations with relatively high soil moisture temporal stability were associated with relatively high clay content, mild slopes, and planar surfaces. In terms of sensitivity to environmental factors (bulk density, SOM, clay content, and canopy density), vegetation type has more influences on the temporal variations of soil moisture under near surface layers (Figs. 4 and 5). Vegetation type may lead to significant differences on soil moisture (Table 2) and its temporal variation (Fig. 2, Table 3 ) below near-surface layers. Nonetheless, the temporal variation of soil moisture in the near-surface layers trends to be more affected by soil/vegetation properties such as bulk density and canopy density (Fig. 5).

Understanding the resulting species-specific differences in patterns of water uptake and the consequences of such differences is of importance for human-influenced ecosystems (Aranda et al., 2012, Bucci et al., 2009). Based on the analysis of soil moisture and its vertical distribution (Table 2, Figs. 2, 3), similar patterns were found among different types of introduced vegetation. Generally, relatively low soil moisture content and high temporal stability were more likely to appear in introduced vegetation as compared with farmland and abandoned farmland. However, the soil moisture in alfalfa and Chinese red pine had relatively higher temporal-averaged values than other types of introduced vegetation, and even more than that in farmland and native grassland (Table 2). This was mainly because of the high canopy density in the understory. Lands with higher canopy density may have higher, more stable soil moisture (Wang et al., 2012a). However, the influence of canopy density on soil moisture was limited at the near-surface layer (Figs. 4, 5). Thus, the temporal variation of soil moisture under nearsurface layers is mainly caused by vegetation type.

Recent studies revealed that the temporal stability of soil moisture declined during the transition period from dry to wet (Gao et al., 2011). Brocca et al. (2007) identified a decreasing trend of variance in soil moisture with increasing mean soil moisture. In this study, low soil moisture was found during May to July, which is the transition period from dry to wet. With the increase in precipitation, relatively high soil moisture and difference appeared from July to the middle of September. However, due to the influence of introduced vegetation restoration, no obvious temporal changes in soil moisture were found in the sub-surface and deep layers. The low SD and CV of soil moisture observed over the three years in the study period indicate that the introduced vegetation induced long-term sustainable soil desiccation in the sub-surface and deep layers. The temporal stable soil desiccation cannot provide enough available soil moisture for plant growth. This will inevitably threaten the sustainability of vegetation restoration and the associated ecosystem services.

\subsection{Soil moisture availability and human-introduced vegetation restoration}

There is an urgent need for better management strategies to avoid the emergence of potential conflicts resulting from poor understanding of the underlying ecohydrological processes (Wang et al., 2012a,b). Introduced vegetation with high planting density and productivity, acting as water pumps, usually consume more soil moisture and disturb the balance between soil moisture and vegetation, leading to soil moisture deficits and soil desiccation (Tan et al., 2011, Yang et al., 2012b). Thus, 
soil moisture availability is not enough to support the long-term growth of human-introduced vegetation. Yang (1996) suggested that areas with mean annual precipitation less than $400 \mathrm{~mm}$ are unsuitable for large-scale human-introduced vegetation restoration, and other researchers have suggested a planting density of 833 plant/ha (Jin et al., 2011). In areas with mean annual precipitation of 400 to $500 \mathrm{~mm}$, the planting density should be approximately 1200 to 2000 plant/ ha for conifer and 750 to 1000 plant/ha for broadleaved trees (Jin et al., 2011; Yang, 1996). The annual precipitation in the study area was lower than $400 \mathrm{~mm}$, and the soil moisture condition was not suitable for high planting density of high water consumption plants. In the study area, the planting density of peashrub was nearly $2222 \mathrm{plant} / \mathrm{ha}$, and the planting density of the forest (Siberian apricot, Chinese red pine and Chinese arborvitae) was nearly 1900 plant/ha. Soil moisture in this area was insufficient for plants with a high planting density. Obviously, the actual planting density in this area is much higher than the recommended value, so it is not surprising to see decreased moisture in the soil layers, especially in the deeper layers. The high planting density may be the main cause of soil moisture deficit and temporal-stable soil desiccation.

The positive effects of vegetation restoration for controlling soil erosion need to be balanced with the negative effects of competing directly for water. To realize sustainable vegetation restoration in semi-arid regions, soil moisture conditions should first be considered. Based on our results, the introduced vegetation will lead to soil moisture deficits, which indicates that large-scale re-vegetation is unsuitable in this area (Wang et al., 2012b). The introduced vegetation restoration projects have been conducted for decades, so a large-scale soil moisture deficit is appearing in the entire Loess Plateau and other semi-arid areas (Chen et al., 2008; Sizemskaya et al., 2009). Furthermore, due to the reliance on afforestation in arid and semi-arid regions' vegetation restoration (Cao et al., 2011), the reasonable planting density should be considered along with soil moisture conditions for vegetation restoration in these areas. Yang et al. (2012a) stated that human-introduced vegetation restoration changed the spatial patterns of deep soil moisture under the influence of topographical factors in the semi-arid Loess Plateau. Thus, detailed locations on watershed scale should also be considered as an issue to target for the big success of eco-construction projects.

\section{Conclusion}

Temporal changes in soil moisture due to vegetation restoration in the semi-arid Loess Plateau were investigated and compared. Results indicated that the soil moisture content decreased drastically after the large-scale vegetation restoration, and temporal-stable soil desiccation appeared in all types of introduced vegetation. The soil moisture deficit was particularly appeared in the sub-surface and deep layers, and significant differences in soil moisture were found below the depth of $0.4 \mathrm{~m}$. Introduced vegetation was the main factor influencing soil moisture deficit below the near-surface layers. Based on the temporal patterns of soil moisture among different vegetation types, the soil moisture was found to be hardly replenished by annual precipitation. The results showed that the soil moisture deficit was temporally stable in the subsurface and deep layers, especially in areas with introduced vegetation. Low available soil moisture and its temporal stability will inevitably affect plant growth, threatening the sustainability of vegetation restoration. High planting density may be the key reason for the severity of the temporally stable soil moisture deficit. For the purpose of achieving sustainable vegetation restoration in semi-arid regions, the approaches of vegetation restoration and planting density should be optimized according to local soil moisture conditions.

\section{Acknowledgments}

We acknowledge the considerable assistance of Baoru Mo with field sampling and laboratory procedures. This study was supported by the
National Natural Science Foundation of China (40925003, 41371123) and China Postdoctoral Science Foundation (2013M530070). We thank the two anonymous reviewers for their constructive comments and suggestions.

\section{References}

Aranda, I., Forner, A., Cuesta, B., Valladares, F., 2012. Species-specific water use by forest tree species: from the tree to the stand. Agric. Water Manag. 114, 67-77.

Brocca, L., Morbidelli, R., Melone, F., Moramarco, T., 2007. Soil moisture spatial variability in experimental areas of central Italy. J. Hydrol. 333, 356-373.

Bucci, S., Scholz, F., Goldstein, G., Meinzer, F., Arce, M., 2009. Soil water availability and rooting depth as determinants of hydraulic architecture of Patagonian woody species. Oecologia 160, 631-641.

Cao, S., Chen, L., Shankman, D., Wang, C., Wang, X., Zhang, H., 2011. Excessive reliance on afforestation in China's arid and semi-arid regions: lessons in ecological restoration. Earth Sci. Rev. 104, 240-245.

Chazdon, R., 2008. Beyond deforestation: restoring forests and ecosystem services on degraded lands. Science 320, 1458-1460.

Chen, L., Huang, Z., Gong, J., Fu, B., Huang, Y., 2007. The effect of land cover/vegetation on soil water dynamic in the hilly area of the Loess Plateau, China. Catena 70, 200-208.

Chen, H., Shao, M., Li, Y., 2008. Soil desiccation in the Loess Plateau of China. Geoderma 143, 91-100.

Chen, L., Wang, J., Wei, W., Fu, B., Wu, D., 2010. Effects of landscape restoration on soil water storage and water use in the Loess Plateau Region, China. For. Ecol. Manag. 259, 1291-1298.

Cheng, X., Huang, M., Shao, M., Warrington, D.N., 2009. A comparison of fine root distribution and water consumption of mature Caragana korshinkii Kom grown in two soils in a semiarid region, China. Plant Soil 315, 149-161.

Cubera, E., Moreno, G., 2007. Effect of land-use on soil water dynamic in dehesas of Central-Western Spain. Catena 71, 298-308.

de Souza, E.R., de Assuncao Montenegro, A.A., Montenegro, S.M.G., de Matos, J.d.A., 2011 Temporal stability of soil moisture in irrigated carrot crops in Northeast Brazil. Agric Water Manag. 99, 26-32.

Du, F., Liang, Z., Xu, X., Zhang, X., 2007. The community biomass of abandoned farmland and its effects on soil nutrition in the Loess Hilly Region of Northern Shaanxi, China. Acta Ecol. Sin. 27 (5), 1673-1683 (in Chinese).

February, E., Higgins, S., 2010. The distribution of tree and grass roots in savannas in relation to soil nitrogen and water. S. Afr. J. Bot. 76 (3), 517-523.

Fu, B., Wang, J., Chen, L., Qiu, Y., 2003. The effects of land use on soil moisture variation in the Danangou catchment of the Loess Plateau, China. Catena 54, 197-213.

Fu, W., Huang, M., Gallichand, J., Shao, M., 2012. Optimization of plant coverage in relation to water balance in the Loess Plateau of China. Geoderma 173-174, 134-144.

Gao, X., Wu, P., Zhao, X., Shi, Y., Wang, J., 2011. Estimating spatial mean soil water contents of sloping jujube orchards using temporal stability. Agric. Water Manag. 102, 66-73.

Grassini, P., You, J., Hubbard, K.G., Gassman, K.G., 2010. Soil water recharge in a semi-arid temperate climate of the Central U.S. Great Plains. Agric. Water Manag. 97 (7), 1063-1069.

Gómez-Plaza, A., Alvarez-Rogel, J., Albaladejo, J., Castillo, V., 2000. Spatial patterns and temporal stability of soil moisture across a range of scales in a semi-arid environment. Hydrol. Process. 14, 1261-1277.

Han, E., Han, G., Bo, Y., 2007. Studies on the growth and soil properties of Pinus tabulaeformis, Platycladus orientalis and Hippophae rhamnoides mixed plantation on Loess Plateau. J. Northwest For. Univ. 22 (3), 100-104 (in Chinese).

Han, F., Zheng, J., Zhang, X., 2009. Plant root system distribution and its effect on soil nutrient on slope land converted from farmland in the Loess Plateau. Trans. Chin. Soc Agric. Eng. 25 (2), 50-55 (in Chinese).

Hupet, F., Vanclooster, M., 2002. Intraseasonal dynamics of soil moisture variability within a small agricultural maize cropped field. J. Hydrol. 261, 86-101.

Jin, T., Fu, B., Liu, G., Wang, Z., 2011. Hydrologic feasibility of artificial forestation in the semi-arid Loess Plateau of China. Hydrol. Earth Syst. Sci. 15, 2519-2530.

Jost, G., Schume, H., Hager, H., Markart, G., Kohl, B., 2012. A hillslope scale comparison of tree species influence on soil moisture dynamics and runoff processes during intense rainfall. J. Hydrol. 420-421, 112-124.

Legates, D.R., Mahmood, R., Levia, D.F., Deliberty, T.L., Quiring, S.M., Houser, C., Nelson, F.E., 2011. Soil moisture: a central and unifying theme in physical geography. Prog. Phys Geogr. 35 (1), 65-86.

Li, P., Li, Z., Hao, M., Zheng, L., 2003. Root distribution characteristics of natural grassland on Loess Plateau. Res. Soil Water Conserv. 10 (1) (144-145, 149 (in Chinese)).

Liu, J., Li, S., Ouyang, Z., Tam, C., Chen, X., 2008. Ecological and socioeconomic effects of China's policies for ecosystem services. Proc. Natl. Acad. Sci. U.S.A. 105 (28), 9477-9482.

Markewitz, D., Devine, S., Davidson, E.A., Brando, P., Nepstad, D.C., 2010. Soil moisture depletion under simulated drought in the Amazon: impacts on deep root uptake. New Phytol. 187, 592-607.

Meerveld, H.J.T., McDonnell, J.J., 2006. On the interrelations between topography, soil depth, soil moisture, transpiration rates and species distribution at the hillslope scale. Adv. Water Resour. 29, 293-310.

Mishra, A.K., Singh, V.P., 2010. A review of drought concepts. J. Hydrol. 391, 202-216.

Mohanty, B.P., Shouse, P.J., van Genuchten, M.T., 1998. Spatio-temporal dynamics of water and heat in a field soil. Soil Tillage Res. 47, 133-143.

Mu, X., Xu, X., Wang, W., Wen, Z., Du, F., 2003. Impact of artificial forest on soil moisture of the deep soil layer on Loess Plateau. Acta Pedol. Sin. 40 (2), 210-217 (in Chinese). 
Porporato, A., D'Odorico, P., Laio, F., Ridolfi, L., Rodriguez-Iturbe, I., 2002. Ecohydrology of water-controlled ecosystems. Adv. Water Resour. 25, 1335-1348.

Qiu, Y., Fu, B., Wang, J., Chen, L., 2001. Spatial variability of soil moisture content and its relation to environmental indices in a semi-arid gully catchment of the Loess Plateau, China. J. Arid Environ. 49, 723-750.

Sala, O., Lauenroth, W., Parton, W., 1992. Long-term soil water dynamics in the shortgrass steppe. Ecology 73, 1175-1181.

Seneviratne, S., Corti, T., Davin, E.L., Hirschi, M., Jaeger, E.B., Lehner, I., Orlowsky, B. Teuling, A.J., 2010. Investigating soil moisture-climate interactions in a changing climate: a review. Earth Sci. Rev. 99, 125-161.

Sizemskaya, M.L., Jiao, J., Wang, N., Sapanov, M., Wu, Q., Jia, Y., Kolesnikow, A., Liu, G. Sapanov, P., 2009. Specificity of afforestation under conditions of moisture deficit in south of the Russian plain and the Loess Plateau of China. Res. Soil Water Conserv. 16 (5), 73-77 (in Chinese)

Sun, G., Zhou, G., Zhang, Z., Wei, X., McNulty, S.G., Vose, J.M., 2006. Potential water yield reduction due to forestation across China. J. Hydrol. 328, 548-558.

Takagi, K., Lin, H.S., 2012. Changing controls of soil moisture spatial organization in the Shale Hills Catchment. Geoderma 173-174, 289-302.

Tan, Z., Zhang, Y., Song, Q., Liu, W., Deng, X., Tang, J., Deng, Y., Zhou, W., Yang, L., Yu, G., Sun, X., Liang, N., 2011. Rubber plantations act as water pumps in tropical China. Geophys. Res. Lett. 38, L24406. http://dx.doi.org/10.1029/2011GL050006.

Teuling, A.J., Troch, P.A., 2005. Improved understanding of soil moisture variability dynamics. Geophys. Res. Lett. 32, 1-4.

Van Pelt, R.S., Wierenga, P.J., 2001. Temporal stability of spatially measured soil matric potential probability density function. Soil Sci. Soc. Am. J. 65, 668-677.

Vivoni, E.R., Rinehart, A.J., Méndez-Barroso, L.A., Aragón, C.A., Bisht, G., Cardenas, M.B., Engle, E., Forman, B.A., Frisbee, M.D., Gutiérrez-Jurado, H.A., Hong, S., Mahmood, T.H., Tai, K. Wyckoff, R.L., 2008. Vegetation controls on soil moisture distribution in the Valles Caldera, New Mexico, during the North American monsoon. Ecohydrology 1, 225-238.

Wang, Y., Shao, M., Shao, H., 2010. A preliminary investigation of the dynamic characteristics of dried soil layers on the Loess Plateau of China. J. Hydrol. 381, 9-17.
Wang, Y., Shao, M., Zhu, Y., Liu, Z., 2011. Impacts of land use and plant characteristics on dried soil layers in different climatic regions on the Loess Plateau of China. Agric. For. Meteorol. 151, 437-448.

Wang, L., D'Odorico, P., Evans, J.P., Eldridge, D.J., McCabe, M.F., Caylor, K.K., King, E.G., 2012a. Dryland ecohydrology and climate change: critical issues and technical advances. Hydrol. Earth Syst. Sci. 16, 2585-2603.

Wang, S., Zhang, Z., McVicar, T., Zhang, J., Zhu, J., Guo, J., 2012b. An event-based approach to understanding the hydrological impacts of different land uses in semi-arid catchments. J. Hydrol. 416-417, 50-59.

Wei, W., Chen, L., Fu, B., Chen, J., 2010. Water erosion response to rainfall and land use in different drought-level years in a loess hilly area of China. Catena 81, 24-31.

Weltzin, J.F., McPherson, G.R., 1997. Spatial and temporal soil moisture resource partitioning by trees and grasses in a temperate savanna, Arizona, USA. Oecologia 112, 156-164.

Wendroth, O., Pohl, W., Koszinski, S., Rogasik, H., Ritsema, C.J., Nielsen, D.R., 1999. Spatiotemporal patterns and covariance structures of soil water status in two NortheastGerman field sites. J. Hydrol. 215, 38-58.

Western, A.W., Grayson, R.B., Bloschl, G., Willgoose, G.R., McMahon, T.A., 1999. Observed spatial organization of soil moisture and its relation to terrain indices. Water Resour. Res. 35 (3), 797-810.

Yang, W., 1996. The preliminary discussion on soil desiccation of artificial vegetation in the northern regions of China. Sci. Silvae Sin. 32 (1), 78-85 (in Chinese).

Yang, L., Wei, W., Chen, L., Jia, F., Mo, B., 2012a. Spatial variations of shallow and deep soil moisture in the semi-arid Loess Plateau, China. Hydrol. Earth Syst. Sci. 16, 3199-3217.

Yang, L., Wei, W., Chen, L., Mo, B., 2012b. Response of deep soil moisture to land use and afforestation in the semi-arid Loess Plateau, China. J. Hydrol. 475, 111-122.

Yang, Z., Hao, J., Bo, Y., Gao, Z., Miao, G., 2012c. Effects of alfalfa root growth on improving immature soil of loess parent material. Acta Agrestia Sin. 20 (3), 489-496 (in Chinese).

Zhao, Z Li, P. 2002. Researches on vertical root distributions and drought resistance of main planting tree species in Weibei Loess Plateau. J. Soil Water Conserv. 16 (1), 96-99 (in Chinese). 